\title{
Effect of Addition of Selected Amino Acids in Semen Extender on Quality and DNA Stability of Frozen-Thawed Sumba Ongole Bull Spermatozoa
}

\author{
Said $\mathrm{S}^{1}$, Setiorini ${ }^{2}$, Adella $\mathrm{M}^{2}$, Sari $\mathrm{I}^{2}$, Fathaniah $\mathrm{N}^{2}$, Maulana $\mathrm{T}^{1}$ \\ ${ }^{1}$ Research Center for Biotechnology, Indonesian Institute of Sciences, Jln. Raya Bogor Km.46 Cibinong 16911. \\ ${ }^{2}$ Department of Biology, Faculty of Mathematics and Natural Science, University of Indonesia. Kampus UI Depok 16424. \\ E-mail: syahruddinsaid01@gmail.com
}

(received 05-10-2018; revised 18-01-2019; accepted 24-01-2019)

\begin{abstract}
ABSTRAK
Said S, Setiorini, Adella M, Sari I, Fathaniah N, Maulana T. 2019 Pengaruh penambahan asam amino terseleksi pada pengencer semen terhadap kualitas dan stabilitas DNA sperma beku sapi Sumba Ongole. JITV 24(1): 15-21. DOI: http://dx.doi.org/10.14334/jitv.v24i1.1873

Penelitian ini bertujuan mengetahui konsentrasi optimal asam amino glutamin, glisin dan sistein dalam tris-citric-acidfructose egg yolks (TCFY) terhadap kualitas spermatozoa sapi Sumba Ongole (SO) selama proses pembekuan dan thawing. Penelitian ini juga mengidentifikasi stabilitas DNA sperma beku. Tiga ekor pejantan dewasa digunakan sebagai donor semen yang dipelihara di PT. Karya Anugerah Rumpin, perusahaan pembibitan sapi swasta, Jawa Barat, Indonesia. Semen dikoleksi menggunakan vagina buatan, dievaluasi sebelum dibekukan. Semen diencerkan dengan TCFY setelah penambahan masingmasing asam amino dengan konsentrasi berbeda $(5,15$ dan $25 \mathrm{mM}$ glisin dan glutamin, dan 3, 5 dan $7 \mathrm{mM}$ sistein) selanjutnya di equilibrasi dan dibekukan. Parameter kualitas sperma yang diamati adalah motilitas, viabilitas, membran plasma utuh, dan stabilitas DNA). Data yang diperoleh memperlihatkan bahwa secara umum pengaruh penambahan asam amino terseleksi (glisin, glutamin dan sistein) kedalam ekstender TCFY terhadap motilitas, viabilitas dan membran plasma utuh sperma sapi SO setelah equilibrasi signifikan $(\mathrm{P}<0,05)$ berbeda lebih baik daripada kontrol. Penambahan $15 \mathrm{mM}$ glisin, $15 \mathrm{mM}$ glutamin dan $5 \mathrm{mM}$ sistein signifikan $(\mathrm{P}<0,05)$ meningkatkan motilitas, viabilitas dan membran plasma utuh sperma setelah thawing dibandingkan control. Ketika sperma difiksasi dengan asam alkohol, diwarnai dengan acridine orange, menunjukkan bahwa seluruh spermatozoa yang diamati DNA nya tetap stabil. Disimpulkan bahwa penambahan $15 \mathrm{mM}$ glisin, glutamin dan $5 \mathrm{mM}$ sistein meningkatkan kemampuan memelihara sperma dalam kondisi beku, dan DNA sperma menunjukkan tetap stabil.
\end{abstract}

Kata Kunci: Kriopreservasi, Semen Sapi, Glisin, Glutamin, Sistein

\section{ABSTRACT}

Said S, Setiorini, Adella M, Sari I, Fathaniah N, Maulana T. 2019. The effect of addition selected amino acids in extender semen on quality and DNA stability of frozen-thawed Sumba Ongole bull spermatozoa. JITV 24(1): 15-21. DOI: http://dx.doi.org/10.14334/jitv.v24i1.1873

The objective of the current study was to asses the optimal concentration of glutamine, glycine and cysteine amino acids in tris-citric-acid-fructose egg yolks (TCFY) extender on quality of SO bull spermatozoa during freezing and thawing. In this study the DNA stability of frozen-thawed Sperm was also indentified. Three mature bulls maintained at PT. Karya Anugerah Rumpin, private cattle breeding company, West Java, Indonesia were used as semen donors. Semen was collected using artificial vagina and were evaluated prior to freezing. Semen was diluted with TCFY supplemented with different concentrations of amino acids (5, 15 and $25 \mathrm{mM}$ glycine and glutamine, and 3, 5 and $7 \mathrm{mM}$ cysteine) then processed for colling and freezing. Semen quality parameters (subjective motility, viability and membrane and DNA integrity). Data showed that in general the effect of addition of selected amino acids (glycine, glutamine and cysteine) into TCFY extenders on motility, viability and membrane integrity of SO spermatozoa after cooling were significantly different $(\mathrm{P}<0.05)$ higher than that of control. Addition of $15 \mathrm{mM}$ glycine, 15 $\mathrm{mM}$ glutamine and $5 \mathrm{mM}$ cysteine resulted in significant $(\mathrm{P}<0.05)$ increase post-thawing sperm motility and sperm viability as compared to that of control. Furthermore, when spermatozoa were stained with acridine orange after fixation with acetic alcohol, the DNA integrity of post-thawing spermatozoa showed that all spermatozoa were remain intact. In conclusion , addition of 15 $\mathrm{mM}$ glycine, glutamine and $5 \mathrm{mM}$ cysteine increase the cryoprotecting efficacy of bovine bull cryopreservation extender, and furthermore all DNA spermatozoa were remain intact.

Key Words: Cryopreservation, Bovine Semen, Glycine, Glutamine, Cysteine

\section{INTRODUCTION}

Sumba ongole (SO) (Bos indicus) cattle is one of Indonesia superior local cattle that plays an important role in meat production for society. It is necessary to improve the population and genetic quality of SO cattle by sperm cryopreservation and artificial insemination (AI). Through this technique, spermatozoa derived from 
superior bulls can fertilize many cattles without any limitations of distance and time (Tsai \& Lin 2012).

Cryopreservation of bull semen is still challenging due to lower fertility when compared to fresh semen because the all processes of cryopreservation including cooling, freezing and thawing create oxidative stress on the sperm membrane (Chatterjee et al. 2001). Freezing/thawing of sperm sample is routinely performed in cattle breeding industries in order to perform artificial insemination. During cryopreservation, semen is exposed to cold shock and atmospheric oxygen, which in turn increases the susceptibility to lipid peroxidation due to higher production of ROS (Bucak et al. 2008). Oxidative stress generally leads to loss of motility, swelling and the blebbing of the acrosomal membrane and disruption or increased permeability of the plasma membrane of spermatozoa (White 1993). It is well known that mammalian spermatozoa contain high concentrations of polyunsaturated fatty acids, and therefore are highly vulnerable to oxidative stress which is responsible for the generation of reactive oxygen species (ROS) (Cassani et al. 2005).

The improvement of cryopreservation technique requires in depth knowledge of the gamete physiology and the biochemical processes occurring during semen collection, processing, and freezing-thawing. Damage due to oxidative stress may be passed by the inclusion of antioxidants prior to freezing processes (Bucak et al. 2008). One of the natural antioxidants present in the seminal plasma is the glutahione (GSH) (Atig et al. 2012). Glutathione is amino acid that formed from glutamine, cysteine, and glycine. However, Glutathione (GSH) in seminal plasma may be reduced by the process of dilution and freezing in cryopreservation. This causes the spermatozoa to be more susceptible to oxidative stress due to the reduced antioxidant content in the plasma seminal (Kutluyer \& Kocabas 2016).

Previous studies reported that the optimal concentrations of glutamine in cryopreservation extender were $25 \mathrm{mM}$ in goat (Ali Al Ahmad et al. 2008), $10 \mathrm{mM}$ in bull (Amirat et al. 2004), $50 \mathrm{mM}$ in stallion (Khlifaouia et al. 2005) and in man (Renard et al. 1996). It was observed that addition of $25 \mathrm{mM}$ of glutamine, $25 \mathrm{mM}$ glycine and $5 \mathrm{mM}$ cyctein increase the cryoprotecting efficacy of buffalo bull cryopreservation extender (El-Sheshtawy et al. 2008). There are no studies on the effect of selected amino acids addition into semen extender on quality of frozenthawed Sumba Ongole bull as well known Indonesian local breed.

The main objective of the current study was to asses the optimal concentration of glutamine, glycine and cysteine amino acids in tris-citric-acid-fructose egg yolks (TCFY) extender on spermatozoa quality of SO bull during freezing and thawing. The stability of frozen-thawed Sperm DNA also indentified in this study.

\section{MATERIALS AND METHODS}

\section{Animal}

Three bulls maintained at PT. Karya Anugerah Rumpin, private cattle breeding company, West Java, Indonesia were used as semen donors. Semen was collected using artificial vagina during mid-morning after an extended period of routine collection every week. Semen quality consist of volume, concentration, motility and abnormality were evaluated prior to freezing. Ejaculates fulfilling minimum standard of sperm motility (70\%) and sperm morphologically normal $(80 \%)$ were used for this study.

\section{Frozen-thawed spermatozoa}

The reference cryopreservation extender as control was Tris-citric-acid-fructose egg yolk (TCFY) diluent, the medium containing Tris (hydroxymethyl) aminomethan $(3.09 \%)$, citrate acid $(1.73 \%)$, fructose $(1.27 \%)$, and added with $20 \%$ (v/v) egg yolk and antibiotic $1 \%(\mathrm{v} / \mathrm{v})$. The amino acids glutamine, glycine (Merck Chemical Co. Germany) were added to the control extender at concentration of $5 \mathrm{mM}, 15 \mathrm{mM}$, and $25 \mathrm{mM}$, while cysteine (Merck Chemical Co. Germany) was added at concentration of $3 \mathrm{mM}, 5 \mathrm{mM}$, and $7 \mathrm{mM}$. Semen was diluted with each extender to provide concentration of 25 million spermatozoa in a $0.25 \mathrm{ml}$ polyvinyl straw. Packed semen in $0.25 \mathrm{ml}$ straw was then equilibrated at $4^{\circ} \mathrm{C}$ for 2 hours, in that time, semen was evaluated. After equilibration periods, the straws were placed horizontally on a rack and frozen in a vapour $5 \mathrm{~cm}$ above liquid nitrogen for 10 minutes, and then dipped in liquid nitrogen (Said et al. 2015).

\section{Assessment of semen quality parameters}

The assessment of SO bull spermatozoa was undertaken on neat semen, equilibration period and freeze thawing. Frozen straws were thawed in waterbath at $37^{\circ} \mathrm{C}$ for 30 seconds. The subjective motility, viability, membrane integrity of spermatozoa performed after equilibration, and after thawing. In addition, evaluation of sperm DNA integrity was performed after thawing.

\section{Sperm motility}

Sperm motility (\%) was assessed subjectively using microscope set at magnification of 200X. Semen sample was diluted 200 times in $\mathrm{NaCl}$ physiological. 
The diluted semen is then dripped on the improved Neubauer chamber and observed. The number of immobilized spermatozoa was calculated first, then after all the spermatozoa did not move, the total sperm was calculated (Akcay et al. 2004).

\section{Sperm viability}

Sperm viability (\%) was assessed using microscope set at magnification 200. Semen sample mixed with eosin $2 \%$, then smeared on object glass. One hundred spermatozoa were assessed and the percentage of unstained (alive) spermatozoa were calculated (WHO 2010).

\section{Sperm membrane integrity}

Sperm membrane integrity $(\%)$ was determined by calculation of the percentage of spermatozoa having intact plasma membrane by osmotic resistance test method (Revell \& Mrode 1994). Hypo-osmotic solution composition comprising: $0.9 \mathrm{~g}$ of fructose, $0.49 \mathrm{~g}$ of sodium citrate were dissolved with aquabidestilata up to a volume of $100 \mathrm{ml}$. A total of $200 \mu \mathrm{L}$ of hypo-osmotic solution was added to $20 \mu \mathrm{L}$ semen, mixed until homogeneous, then incubated at $37^{\circ} \mathrm{C}$ for 45 minutes. Semen samples were smeared on a glass object and evaluated with 400X magnification. One hundred spermatozoa were assesed and the percentage of spermatozoa with curled tail (swelling) were calculated.

\section{Sperm DNA integrity}

DNA integrity of frozen-thawed spermatozoa was evaluated by using acridine orange staining technique. Samples of spermatozoa were smeared on glass slides, air-dried, fixed for $2 \mathrm{~h}$ in acetic alcohol (1 part glacial acetic acid plus 3 parts $100 \%$ methanol) and air- dried again. After fixation, sperm samples were stained with acridine orange solution (at 1000x dilution with GLPBS) overnight (Said et al. 2003). After staining, each slide was washed with distilled water and sealed with synthetic resin to prevent it from drying. Slides were examined with fluorescence microscope (Axiophot Zeiss; 490/530 nm excitation/barrier filter). Two hundred cells were analyzed in each treatment slide. Sperm with normal DNA content presented a green fluorescence, whereas sperm with abnormal DNA content emited fluorescence in a spectrum varying from yellow to green. The percentage of sperm with intact chromatin was calculated by dividing the number of green-stained sperm by the total number of sperm and multiplying the result by 200 (Said et al. 1999).

\section{Statistical analysis}

The data were analyzed using Statistical Product and Service Solution (SPSS) version 24. Data normality was tested using Shapiro \& Wilk test, then homogenity was tested using Levene test. The data were normally distributed and homogeneously varied, so the test continued using a one-factor variance analysis (ANOVA) test and continued with the Tukey test to see whether there were differences between treatments (Zar 1974).

\section{RESULTS AND DISCUSSION}

\section{Quality of frozen-thawed Sumba Ongole bull spermatozoa}

The effect of addition selected of amino acids (glycine, glutamine and cysteine) to TCFY extenders used for processing of SO bulls semen on motility, viability, membrane integrity after equilibration period summarized in Table 1.

These data showed that in general the effect of addition of selected amino acids (glycine, glutamine and cysteine) to TCFY extenders on motility, viability and membrane integrity of $\mathrm{SO}$ spermatozoa after equilibration were significantly $(\mathrm{P}<0.05)$ higher than that of control. Except in cysteine $3 \mathrm{mM}$ and $7 \mathrm{mM}$ the effect on viability and membrane integrity sperm were not significantly different $(\mathrm{P}>0.05)$ than control. The data also indicated that within each amino acid, additions of $5 \mathrm{mM}$ glycine and $15 \mathrm{mM}$ glutamine enhance sperm motility, whereas $5 \mathrm{mM}$ cysteine enhance sperm motility, viability and membrane integrity during equilibration.

The effect of addition of selected amino acids (glycine, glutamine and cysteine) to TCFY extenders used for processing of SO bulls semen on motility, viability, membrane integrity post-thawing summarized in Table 2.

Data in Table 2 shows that addition of $15 \mathrm{mM}$ glycine, $15 \mathrm{mM}$ glutamine and $5 \mathrm{mM}$ cysteine resulted in significant $(\mathrm{P}<0.05)$ increase post-thawing sperm motility and sperm viability as compared to the control. However, addition of selected amino acids to the extender were not significantly different on membrane integrity with no further significant enhancement of sperm motility, viability could be noticed when glycine and glutamine were added at concentration of $15 \mathrm{mM}$ and cysteine of $5 \mathrm{mM}$.

The cryopreservation of semen includes the decrease in temperature and increase in oxidative stress 
Table 1. Effect of different concentrations of selected amino acids on characteristics of SO bull spermatozoa after equilibration $($ Mean \pm SE)

\begin{tabular}{llccc}
\hline \multirow{2}{*}{ Treatment } & & \multicolumn{3}{c}{ Semen characteristics } \\
\cline { 3 - 5 } Control & & Motility & Viability & Membrane integrity \\
\hline Glycine & $5 \mathrm{mM}$ & $53.02 \pm 0.35$ & $54.41 \pm 1.10$ & $56.08 \pm 1.31$ \\
& $15 \mathrm{mM}$ & $57.38 \pm 0.26^{\mathrm{ab} *}$ & $57.41 \pm 0.86^{*}$ & $58.45 \pm 0.50^{*}$ \\
& $25 \mathrm{mM}$ & $55.95 \pm 0.80^{\mathrm{b} *}$ & $57.58 \pm 0.21^{*}$ & $58.25 \pm 0.52^{*}$ \\
\hline Glutamine & $5 \mathrm{mM}$ & $57.86 \pm 0.80^{\mathrm{a} *}$ & $57.91 \pm 0.66^{*}$ & $58.50 \pm 0.54^{*}$ \\
& $15 \mathrm{mM}$ & $60.39 \pm 0.77^{\mathrm{b} *}$ & $58.66 \pm 0.51^{*}$ & $59.66 \pm 0.6 \mathrm{a}^{*}$ \\
& $25 \mathrm{mM}$ & $59.11 \pm 0.42^{\mathrm{ab} *}$ & $58.08 \pm 0.58^{*}$ & $59.58 \pm 0.58^{*}$ \\
\hline Cysteine & $3 \mathrm{mM}$ & $55.10 \pm 0.93^{\mathrm{a} *}$ & $55.16 \pm 1.47^{\mathrm{a}}$ & $59.50 \pm 0.71^{*}$ \\
& $5 \mathrm{mM}$ & $57.16 \pm 1.16^{\mathrm{b} *}$ & $57.50 \pm 0.54^{\mathrm{b} *}$ & $56.83 \pm 1.32^{\mathrm{a}}$ \\
& $7 \mathrm{mM}$ & $55.83 \pm 1.47^{\mathrm{ab} *}$ & $55.66 \pm 1.03^{\mathrm{a}}$ & $59.11 \pm 0.77^{\mathrm{b} *}$ \\
& & & $57.91 \pm 0.49^{*}$ & $57.00 \pm 1.54^{\mathrm{a}}$ \\
\hline
\end{tabular}

Within each amino acid, means with different alphabetical superscripts are significantly different $(\mathrm{P}<0.05)$

Within columns, $(*)$ indicates significant difference $(\mathrm{p}<0.05)$ of a given element from control

Table 2. Effect of different concentrations of selected amino acids on characteristics of SO bull spermatozoa post thawing (Mean $\pm \mathrm{SE})$

\begin{tabular}{lcccc}
\hline \multirow{2}{*}{ Treatment } & & \multicolumn{3}{c}{ Semen characteristics } \\
\cline { 3 - 4 } Control & & Motility & Viability & Membrane integrity \\
\hline Glycine & $5 \mathrm{mM}$ & $47.38 \pm 0.44$ & $51.02 \pm 0.63$ & $52.67 \pm 0.79$ \\
& $15 \mathrm{mM}$ & $49.51 \pm 0.61^{\mathrm{a}}$ & $52.85 \pm 0.35$ & $54.02 \pm 1.02$ \\
& $25 \mathrm{mM}$ & $52.53 \pm 1.68^{\mathrm{b}} *$ & $54.50 \pm 1.37^{*}$ & $54.22 \pm 0.92$ \\
Glutamine & $5 \mathrm{mM}$ & $50.35 \pm 1.18^{\mathrm{ab} *}$ & $53.75 \pm 1.66^{*}$ & $52.97 \pm 1.81$ \\
& $15 \mathrm{mM}$ & $49.60 \pm 2.18^{\mathrm{a}}$ & $53.58 \pm 0.80^{*}$ & $54.25 \pm 1.89$ \\
& $25 \mathrm{mM}$ & $52.98 \pm 1.43^{\mathrm{b}} *$ & $53.58 \pm 1.15^{*}$ & $54.75 \pm 1.03$ \\
\hline Cysteine & $3 \mathrm{mM}$ & $50.87 \pm 1.22^{\mathrm{ab} *}$ & $53.16 \pm 1.63$ & $53.75 \pm 2.42$ \\
& $5 \mathrm{mM}$ & $47.50 \pm 1.22^{\mathrm{a}}$ & $52.83 \pm 2.04$ & $51.50 \pm 2.58$ \\
& $7 \mathrm{mM}$ & $51.00 \pm 2.19^{\mathrm{b} *}$ & $55.00 \pm 1.26^{*}$ & $54.33 \pm 1.63$ \\
\hline
\end{tabular}

Within each amino acid, means with different alphabetical superscripts are significantly different $(\mathrm{P}<0.05)$

Within columns, $(*)$ indicates significant difference $(\mathrm{P}<0.05)$ of a given element from control

on the sperm membrane which resulted in irreversible damage to intracellular structures and changes in enzymatic activity and associated reduction in motility, fertilizing ability of spermatozoa (Kumar et al. 2011). Amino acids are the constituents of the seminal plasma and have been used in different combinations in extenders for the cryopreservation of semen in different livestock species (Farshad \& Hosseini 2013; Sarıözkan et al. 2014; El-Sheshtawy et al. 2008).
In the present study, the supplementation of amino acids (glutamine, cysteine, glycine) to TCFY extenders improved the spermatozoa quality with respect to the motility, viability and membrane integrity both after the equilibration and post-thaw. Although, the mechanism of action of the amino acids as a cryoprotectant is still not clear but many authors have reported that the amino acids possess the anti-oxidative capacity (Farshad \& Hosseini 2013; Bucak et al. 2009; Topraggaleh et al. 
2014) which may be attributed to its cryoprotective nature.

Data resuled showed similarity to the data from previous study (Khalili et al. 2010) that post-thawing sperm motility and viability were significantly improved at concentrations between 5 to $15 \mathrm{mM}$ of glycine and cysteine, and $15 \mathrm{mM}$ glutamine (Purwasih et al. 2013). Kundu et al. (2001) reported that lower concentration (20-70 mM) of glycine and glutamine manifest their cryoprotecting efficacy on goat sperm in the presence of glycerol or dimethyl sulfoxide. Khlifaouia et al. (2005) suggested that glutamine could have synergistic cryoprotective role with glycerol on cryopreservation of stallion spermatozoa and its penetration to sperm cells is very low, thus glutamine may play a cryoprotective role at extracellular level. Ali Al Ahmad et al. (2008) showed that glutamine has a cryoprotective effect during the freezing/thawing process of goat sperm. Previous studies reported that the optimal concentrations of glutamine in cryopreservation extender were $25 \mathrm{mM}$ in goat (Ali $\mathrm{Al}$ Ahmad et al. 2008), $10 \mathrm{mM}$ in bull (Amirat et al. 2004), $30 \mathrm{mM}$ (Trimeche et al. 1999) or $50 \mathrm{mM}$ in stallion (Khlifaouia et al. 2005) and in man (Renard et al. 1996).

Result of this research, clearly indicated that the addition of glutamine, glycine, and cysteine in the conventional freezing medium increased post-thawed motility and improved membrane and acrosome integrity of SO bull semen. These results were in line with the results obtained from buffalo bull semen (ElSheshtawy et al. 2008). It is well known that mammalian spermatozoa contain high concentrations of polyunsaturated fatty acids, and therefore are highly vulnerable to oxidative stress which is responsible for the generation of reactive oxygen species (ROS) (Cassani et al. 2005). Oxidative stress generally leads to loss of motility, swelling and the blebbing of the acrosomal membrane and disruption or increased permeability of the plasma membrane of spermatozoa. Bilodeau et al. (2001) demonstrated that thiol-radicals containing amino acids, such as glutathione, cysteine, $\mathrm{N}$-acetyl-cysteine and 2 mercapto ethanol, prevented hydrogen peroxide mediated loss of sperm motility in frozen-thawed bull semen.

\section{DNA stability of frozen-thawed Sumba Ongole bull spermatozoa}

The result observation of the DNA integrity of frozen-thawed spermatozoa are presented in Table 3 and Figure 1.

The DNA integrity of frozen-thawed spermatozoa after fixation with acetic alcohol and stained with acridine orange showed all spermatozoa were green color. These results indicats that all spermatozoa in the control treatment as well as with the addition of amino acids have a stable DNA content. The DNA of mammalian sperm is mostly known as the most compact eukaryotic DNA which is packaged more tightly than the tightly packaged mitotic chromosomes of somatic cells (Ward \& Coffey 1991). In this study, identification of DNA damage using acridine orange test, the DNA damaged and intact sperm were classified subjectively under florescence microscope. Acridine orange inserts between nitrogenous bases in double stranded DNA (DS-DNA) as monomers. This makes spermatozoa produced green color when observed with a fluorescence microscope. If the DNA molecule consists of single stranded, acridine orange will join the

Table 3. DNA integrity of frozen-thawed SO cattle spermatozoa using acridine orange method

\begin{tabular}{lccc}
\hline \hline \multirow{2}{*}{ Treatments } & & DNA Integrity $(\%)$ & No Intact \\
\hline Control & & Intact & $0(0.00)$ \\
Glycine & $5 \mathrm{mM}$ & $200(100.00)$ & $0(0.00)$ \\
& $15 \mathrm{mM}$ & $200(100.00)$ & $0(0.00)$ \\
& $25 \mathrm{mM}$ & $200(100.00)$ & $0(0.00)$ \\
Glutamine & $5 \mathrm{mM}$ & $200(100.00)$ & $0(0.00)$ \\
& $15 \mathrm{mM}$ & $200(100.00)$ & $0(0.00)$ \\
& $25 \mathrm{mM}$ & $200(100.00)$ & $0(0.00)$ \\
Cysteine & $3 \mathrm{mM}$ & $200(100.00)$ & $0(0.00)$ \\
& $5 \mathrm{mM}$ & $200(100.00)$ & $0(0.00)$ \\
& $7 \mathrm{mM}$ & $200(100.00)$ & $0(0.00)$ \\
\hline
\end{tabular}




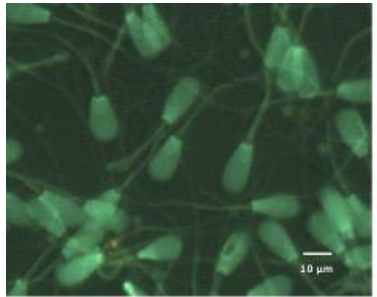

Control

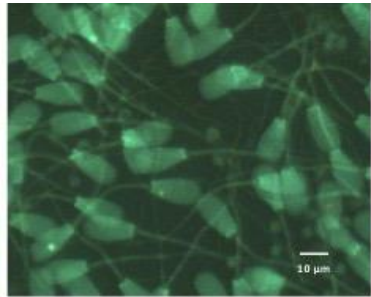

Glutamine

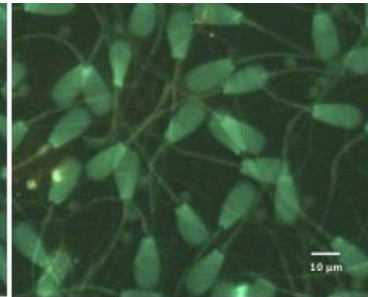

Glycine

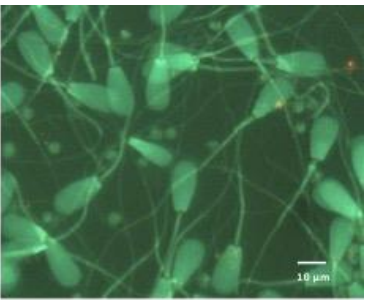

Cysteine

Figure 1. DNA integrity of frozen-thawed SO cattle spermatozoa using fluorescence microscope.

DNA into a single unit, and when observed with a fluorescence microscope, the spermatozoa will produce a red color (Morshedi 2014; Evenson 2016). The color produced by acridine orange in spermatozoa depends on the thiol-disulfide status of the protamine. In immature spermatozoa (immature), the protamine contains thiol. This causes DNA in immature spermatozoa to be denatured become single stranded by acid. When spermatozoa undergo maturation in the epididymis, thiol on the protamine will change gradually into disulfide. This causes DNA in mature spermatozoa to be resistant to acid-induced denaturation, so the DNA will remain double stranded (Said \& Niwa 2004).

In the present study, when spermatozoa were stained with acridine orange after fixation with acetic alcohol, the DNA integrity of frozen-thawed spermatozoa showed that all spermatozoa were green color. These results indicate that all spermatozoa in the control treatment as well as with the addition of amino acids have a stable DNA content. Oxidative stress occurs due to the imbalance between the production of reactive oxygen species and antioxidant defense system. It was reported that ROS production pathologically results in high levels of DNA damage that is associated with properties of mitochondrial membrane (Hosen et al. 2015). The structure of the plasma membrane is unique and consists of high levels of polyunsaturated fatty acids (PUFAs) that improve membrane flexibility. It makes them vulnerable to be attacked by ROS (Sheweita et al. 2005). Lipid peroxidation cascade can seriously compromise the functional integrity of membrane cells, decrease sperm motility, and subsequently reduce fertility.

\section{CONCLUSION}

In conclusion the current study demonstrated that addition of $15 \mathrm{mM}$ glycine, $15 \mathrm{mM}$ glutamine and 5 $\mathrm{mM}$ cysteine increase the cryoprotecting efficacy of SO bull cryopreservation extender, and furthermore all DNA spermatozoa were remain intact. However, further studies still needed to observ the effect of combined amino acids addition.

\section{ACKNOWLEDGEMENT}

The authors would like to thank Research Center for Biotechnology, Indonesian Institute of Sciences and PT. Karya Anugerah Rumpin for the permission to use farm facilities. Author gratitude is also expressed to members of Animal Research Group in Research Center for Biotechnology, Indonesian Institute of Sciences.

\section{REFERENCES}

Akcay E, Bozkurt Y, Secer S, Tekun N. 2004. Cryopreservation of mirror carp semen. Turkey $\mathrm{J}$ Vet Anim Sci. 28:837-843.

Ali Al Ahmad MZ, Chatagnon G, Amirat-Briand L, Moussa M, Tainturier D, Anton M, Fieni F. 2008. Use of glutamine and low density lipoproteins isolated from egg yolk to improve buck semen freezing. Reprod Domest Anim. 43:768

Amirat L, Tainturier D, Jeanneau L, Thorin C, Gerard O, Courtens J, Anton M. 2004. Bull semen in vitro fertility after cryopreservation using egg yolk ldl: a comparison with optidyl, a commercial egg yolk extender. Theriogenology. 61: 895-907.

Atig F, Raffa M, Ali Habib B, Kerkeni A, Saad A, Ajina M. 2012. Impact of seminal trace element and glutathione levels on semen quality of Tunisian infertile men. BMC Urol. 12:6.

Bilodeau JF, Blanchette S, Gagnon C, Sirard MA. 2001. Thiols prevent $\mathrm{H} 2 \mathrm{O} 2$-mediated loss of sperm motility in cryopreserved bull semen. Theriogenology. 56:275-286.

Bucak MN, Atessahin A, Abdurrauf Y. 2008. Effect of antioxidants and oxidative stress parameters on ram after the freeze-thawing process. Small Rumin Res. 75:128-134.

Bucak MN, Tuncer PB, Sarı̈zkan S, Ulutaş PA. 2009. Comparison of the effects of glutamine and an amino acid solution on post-thawed ram sperm parameters, lipid peroxidation and anti-oxidant activities. Small Rumin Res. 81:13-17.

Cassani P, Beconi MT, O’Flaherty C. 2005. Relationship between total superoxide dismutase activity with lipid peroxidation, dynamics and morphological parameters in canine semen. Anim Reprod Sci. 86:163-173. 
Chatterjee S, De Lamirande E, Gagnon C. 2001. Cryopreservation alters membrane sulfhydryl status of bull spermatozoa: protection by oxidized glutathione. Mol Reprod Dev. 60:498-06.

El-Sheshtawy RI, El-Sisy GA, El-Nattat WS. 2008. Use of selected amino acids to improve buffalo bull semen cryopreservation. Glob Vet. 2:146-150.

Evenson DP. 2016. The sperm chromatin structure assay (SCSA) and other sperm DNA fragmentation tests for evaluation of sperm nuclear DNA integrity as related to fertility. Anim Reprod Sci. 169: 56-75.

Farshad A, Hosseini Y. 2013. The cryoprotective effects of amino acids supplementation on cooled and post- thaw Markhoz bucks semen quality. Small Rumin Res. 114:258-263.

Hosen MB, Islam MR, Begum F, Kabir Y, Howlader MZH. 2015. Oxidative stress induced sperm DNA damage, a possible reason for male infertility. Iran J Reprod Med. 13:525-532.

Khalili B, Jafaroghli M, Farshad A, Paresh-Khiavi M. 2010. The effects of different concentrations of glycine and cysteine on the freezability of moghani ram spermatozoa. Asian-Aust J Anim Sci. 23:318-325.

Khlifaouia M, Battuta I, Bruyasa JF, Chatagnona G, Trimecheb A, Tainturiera D. 2005. Effects of glutamine on post-thaw motility of stallion spermatozoa: an approach of the mechanism of action at spermatozoa level. Theriogenology. 63:138-149.

Kumar R, Mohanarao GJ, Atreja SK. 2011. Freeze: Thaw induced genotoxicity in buffalo (Bubalus bubalis) spermatozoa in relation to total antioxidant status. Mol Biol Rep. 38:1499-1506.

Kundu CN, Das K, Majumder GC. 2001. Effect of amino acids on cauda epididymal sperm cryopreservation using a chemically defined model system. Cryobiology. 41:21-27.

Kutluyer F, Kocabas M. 2016. Use of amino acids in fish sperm cryopreservation: A Review. Austin Biol. 1:1-4.

Morshedi M. 2014. Human sperm nuclear DNA fragmentation assays and their values in assisted. College of reproductive biology 18th annual symposium: 1-15.

Purwasih R, Ondho YS, Sutopo. 2013. Efektivitas prefreezing semen Sapi Jawa sebagai parameter keberhasilan processing semen beku. Anim Agric J. 2:44-50.

Renard P, Grizard G, Griveau JF, Sion B, Boucher D, Le Lannou D. 1996. Improvement of motility and fertilization potential of post-thaw human sperm using amino acids. Cryobiology. 33:311-319.
Revell SG, Mrode R. 1994. An osmotic resistance test for bovine semen. Anim Reprod Sci. 36:77-86.

Said S, Afiati F, Maulana T. 2015. Study on changes of sperm head morphometry and DNA integrity of freeze-dried bovine spermatozoa. J Indones Trop Anim Agric. 40:145-152

Said S, Funahashi H, Niwa K. 1999. DNA stability and thioldisulphide status of rat sperm nuclei during epididymal maturation and penetration of oocytes. Zygote 7:249254.

Said S, Han MS, Niwa K. 2003. Development of rat oocytes following intracytoplasmic injection of sperm heads isolated from testicular and epididymal spermatozoa. Theriogenology. 60:359-369.

Said S. Niwa K. 2004. Keberhasilan ICSI tergantung pada stabilitas DNA dan status disulfida inti spermatozoa. JITV. 9:210-215.

Sarıözkan S, Özdamar S, Türk G, Cantürk F, Yay A. 2014 In vitro effects of 1-carnitine and glutamine on motil- ity, acrosomal abnormality, and plasma membrane integrity of rabbit sperm during liquid-storage. Cryobiology. 68:349-353.

Sheweita SA, Tilmisany AM, Al-Sawaf H. 2005. Mechanisms of male infertility: role of antioxidants. Curr Drug Metab. 6:495-501.

Topraggaleh TR, Shahverdi A, Rastegarnia A, Ebrahimi B, Shafiepour V, Sharbatoghli M, Esmaeili V, Janzamin E. 2014. Effect of cysteine and glutamine added to extender on post-thaw sperm functional parame- ters of buffalo bull. Andrologia. 46:777-783.

Trimeche A, Yvon JM, Vidament M, Palmer E, Magistrini M. 1999. Effects of glutamine, proline, histidine and betaine on post-thaw motility of stallion spermatozoa. Theriogenology. 52:181-191.

Tsai S, Lin C. 2012. Advantages and applications of cryopreservation in fisheries Fscience. Braz Arch Biol Technol. 55:425-433.

Ward WS, Coffey DS. 1991. DNA packaging and organization in mammalian spermatozoa: Comparison with somatic cells. Biol Reprod. 44:569-74

White IG. 1993. Lipids and calcium uptake of sperm in relation to cold shock and preservation: a review. Reprod Fertil Dev. 5:639-658.

[WHO] World Health Organization. 2010. WHO laboratory manual for the examination and processing of human semen. 5th ed. Geneva (Switzerland): World Health Organization. p. 260.

Zar JH. 1974. Biostatistical analysis. London (UK): PrenticeHall, Inc. p. 620. 